\title{
U norden
}

Pohjoismaiden ministerineuvoston toiminta Vuosikertomus 2014 

2 norden 



\section{Pohjoismaiden ministerineuvoston toiminta}

Vuosikertomus 2014 
Pohjoismaiden ministerineuvoston toiminta

Vuosikertomus 2014

ISBN 978-92-893-4326-8 (PRINT)

ISBN 978-92-893-4327-5 (PDF)

http://dx.doi.org/10.6027/ANP2015-769

ANP 2015:769

(C) Pohjoismaiden ministerineuvosto 2015

Ulkoasu: Cecilie Ravik

Kannen valokuva: ScanPrint

www.norden.org/nordpub

\section{Pohjoismainen yhteistyö}

Pohjoismainen yhteistyö on yksi maailman laajimpia alueellisia yhteistyömuotoja. Yhteistyön piiriin kuuluvat Islanti, Norja, Ruotsi, Suomi ja Tanska sekä Ahvenanmaa, Färsaaret ja Grönlanti.

Pohjoismaista yhteistyötä tehdään politiikan, talouden ja kulttuurin aloilla tärkeänä osana eurooppalaista ja kansainvälistä yhteistyötä. Pohjoismaisen yhteisön tavoitteena on vahva Pohjola vahvassa Euroopassa.

Pohjoismainen yhteistyö pyrkii vahvistamaan pohjoismaisia ja alueellisia etuja ja arvoja globaalissa maailmassa. Maiden yhteiset arvot lujittavat osaltaan Pohjolan asemaa yhtenä maailman innovatiivisimmista ja kilpailukykyisimmistä alueista.

Pohjoismaiden ministerineuvosto

Ved Stranden 18

DK-1061 København K

Puhelin (+45) 33960200

www.norden.org 


\section{Sisällysluettelo}

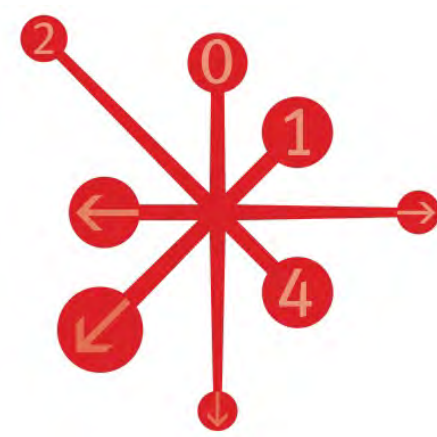

Esipuhe.. . .7

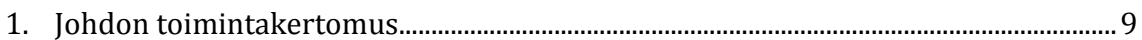

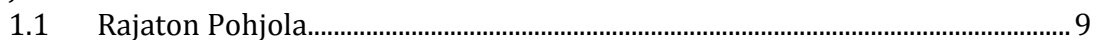

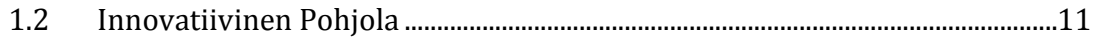

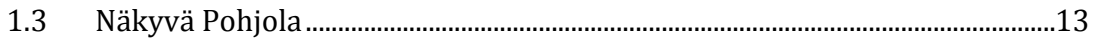

$1.4 \quad$ Ulospäin suuntautunut Pohjola ............................................................................15

2. Budjetti 2014 - Pohjoismaiden neuvoston kanssa käytyjen neuvottelujen seuranta. 



\section{Esipuhe}

Yhdessä olemme vahvempia on pohjoismaisen yhteistyön visio, josta Pohjoismaiden yhteistyöministerit sopivat helmikuussa 2014. Samana kesänä vision sisältö tarkentui, kun tehtiin päätös ministerineuvoston työn uudistamisesta.

Uudistustyön ensisijainen tavoite on vahvistaa jäsenmaiden dynaamista ja tärkeää yhteistyötä, jotta maat saisivat yhdessä aikaan parempia tuloksia kuin kukin erillään.

Yksi tämän vuosikertomuksen tavoitteista on tuoda esiin yhteistyön tuloksia vision neljältä osa-alueelta: rajaton Pohjola, innovatiivinen Pohjola, näkyvä Pohjola ja ulospäin suuntautunut Pohjola.

Vuonna 2014 Pohjoismaiden ministerineuvoston puheenjohtajana toimi Islanti.

Puheenjohtajakauden ohjelmaan kuului kolme päähanketta: pohjoismainen biotalous, pohjoismainen hyvinvointivahti ja pohjoismainen soittolista. Nämä Islannin käynnistämät aloitteet jatkuvat vuoden 2016 loppuun saakka.

Vuonna 2014 Pohjoismaiden ministerineuvosto juhlisti kahta vuosipäivää. Yhteispohjoismaiset työmarkkinat ovat toimineet 60 vuotta ja pohjoismainen tasa-arvoyhteistyö täytti 40 vuotta.

Yhteistä molemmille aloille on se, että kuluneiden vuosikymmenten työ on ollut menestyksekästä, mutta vielä on paljon tehtävää.

Edelleen on asioita, jotka estävät työvoiman täyden liikkuvuuden Pohjoismaiden välillä. Työ näiden esteiden poistamiseksi jatkuu ja sen tavoitteena on, että yhdestä Pohjoismaasta toiseen muuttaminen olisi yhtä helppoa kuin kunnasta toiseen muuttaminen kotimaassa.

Tasa-arvoalan nykyhaasteista voidaan mainita muun muassa poikien ja tyttöjen stereotyyppiset käyttäytymismallit, jotka rajoittavat sekä koulutukseen että työelämään liittyviä mahdollisuuksia.

Pohjoismainen yhteiskuntamalli herättää entistä suurempaa kiinnostusta myös Pohjoismaiden ulkopuolella. Tätä kiinnostusta hyödynnetään tehokkaasti muun muassa Pohjoismaiden kansainvälisen profilointi- ja asemointistrategian avulla, josta yhteistyöministerit päättivät Pohjoismaiden neuvoston Tukholman-istunnon yhteydessä lokakuussa. Strategiassa keskitytään Pohjoismaille tunnusomaisiin vahvuuksiin ja arvoihin, muun muassa avoimuuteen, luottamukseen kanssaihmisiä sekä päättäjiä 
kohtaan sekä lähimmäisen huomioimiseen. Nykyajan entistä globaalimmassa maailmassa nämä arvot ovat yhä tärkeämpiä meille pohjoismaalaisille ja sitäkin kiinnostavampia inspiraationlähteitä myös muille. Tämän huomioiminen on yksi profilointistrategian pyrkimyksistä.

Kööpenhaminassa 1. heinäkuuta 2015

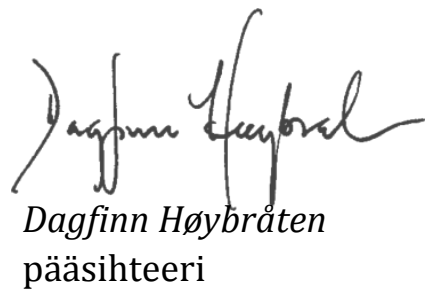

Pohjoismaiden ministerineuvosto 


\section{Johdon toimintakertomus}

\subsection{Rajaton Pohjola}

\subsubsection{Rajaton Pohjola tuo miljardivoitot}

Noin 70000 pohjoismaalaista asuu yhdessä Pohjoismaassa ja työskentelee toisessa. Mitä rajattomampi Pohjola on, sitä nopeampaa on alueen talouskasvu; kilpailukyky vahvistuu ja syntyy uusia työpaikkoja.

Jo nykyisellään toisessa Pohjoismaassa työssäkäyvien työpanos Pohjoismaiden sisällä on taloudellisesti kannattavaa; vuonna 2014 sen arvo oli noin 5,6 miljardia euroa.

Ruotsalaiset pitävät koko Pohjolaa yhtenä työmarkkina-alueena useammin kuin muut pohjoismaalaiset. Noin 80 prosenttia kaikista päivittäin toisessa maassa työssäkäyvistä asuu Ruotsissa.

Norja puolestaan voittaa rajojen yli kulkevan työmatkaliikenteen myötä taloudellisesti eniten. Noin 60 prosentilla muussa kuin kotimaassaan työskentelevistä on norjalainen työnantaja. Rajan yli kulkeva työmatkaliikenne tuo Norjan taloudelle vuosittain kasvua noin 4,3 miljardin euron verran.

Myös Tanskan talous hyötyy työntekijöistä, jotka tulevat päivittäin Tanskaan töihin toisesta maasta. Tanskaan päin päivittäin töihin kulkevia on 13000 enemmän kuin Tanskasta toiseen suuntaan - suurin osa tulijoista on Ruotsista. Nämä toisessa maassa asuvat työntekijät tuovat Tanskan taloudelle noin 1 miljardin euron tulot vuodessa.

Työssäkäynti toisessa maassa vähentää työttömyyskustannuksia maissa, joissa monet asukkaat työskentelevät toisessa Pohjoismaassa. Näin on etenkin Ruotsissa ja Suomessa.

Pohjoismaiden pääministerin aloitteesta pohjoismaiset yhteistyöministerit perustivat 1. tammikuuta 2014 uuden rajaesteneuvoston Pohjoismaiden rajaestetyön tehostamiseksi.

Rajaesteneuvoston työ on jaettu kolmeen osa-alueeseen:

- Pohjoismaiden välisten rajaesteiden poistaminen

- uusien rajaesteiden ennaltaehkäisy

- tiedotuksen lisääminen ja tehostaminen.

Vuonna 2014 rajaesteneuvoston puheenjohtajana toimi Siv Friðleifsdóttir. 


\subsubsection{Veroparatiisijahti}

Pohjoismailla on yhteinen hanke, joka on jo tuottanut miljarditulot. Sen virallinen nimi on Pohjoismainen yhteistyö verotietojen vaihtosopimusten solmimiseksi offshore-rahoituskeskusten kanssa. Kansa puhuisi todennäköisesti "veroparatiisijahdista".

Hanke on ollut menestystarina, joka on mullistanut kansainvälisen veropoliittisen kartan. Tämän yhteistyöhankkeen ansiosta Pohjoismailla on nyt lähes aukoton tiedonvaihtosopimusten verkosto niiden maiden kanssa, joissa on pankkisalaisuus tai muita lainsäädännöllisiä rajoituksia verotuksen avoimuudelle.

Pohjoismaisille veronkiertäjille ei siis enää löydy turvapaikkoja. Poikkeuksena on vain Yhdistyneet arabiemiirikunnat, jonka kanssa käydään kuitenkin jo neuvotteluja.

Viime vuosisadalla veronkierto oli varsin rajallista, mutta se lisääntyi räjähdysmäisesti 1970-1980-lukujen globalisaatioprosessin myötä. Yksityishenkilöiden ja yritysten pääomien liikkuvuus vapautettiin, eivätkä kansalliset viranomaiset voineet muuta kuin katsoa vierestä.

Pohjoismaat käynnistivät yhteisen aloitteen, kun OECD:n aloittamat haitallisen verokilpailun vastatoimet hiipuivat 2000-luvun alussa. Toivomuksena oli, että OECD:n esittämien kollektiivisten rangaistusten avulla saataisiin aikaan sopimukset parin maan kanssa, ja loppujen 40 maan kanssa varauduttiin raskaisiin neuvotteluihin.

Pohjoismaiden yhteishanke ylitti kuitenkin kaikki odotukset. Ajoitus oli täydellinen, sillä samaan aikaan kansainvälisen yhteisön katseet kohdistuivat veronkiertoon ja terrorismin rahoittamiseen. Muutama vuosi hankkeen aloittamisen jälkeen G20-ryhmä nosti kysymyksen kansainvälisen tärkeysjärjestyksen kärkeen ja perusti vuonna 2009 verotusta koskevaa avoimuutta ja tietojenvaihtoa käsittelevän maailmanlaajuisen foorumin. Pohjoismaat ovat nyt niitä harvoja maita, joilla on käytännössä aukoton tietojenvaihtosopimusten verkosto.

Kaikille on selvää, että tämä ei olisi onnistunut ilman pohjoismaista yhteistyötä. Yksittäiset Pohjoismaat olisivat olleet liian pieniä ollakseen kiinnostavia neuvottelukumppaneita.

Työ jatkuu Pohjoismaiden kansainvälisessä veronkiertotyöryhmässä (NAIS), ja tässä vaiheessa käsitellään verosopimusten soveltamista.

Verotietojen saantia tulee myös parantaa entisestään. Tavoitteena on lisätä automatisointia, ja sen kautta helpottaa tietojenvaihtoa.

Pohjoismaat ovat valinneet hieman eri tapoja työssään, mutta ovat yksimielisiä siitä, että tulos on ollut parempi kuin uskallettiin toivoa. Norjan verohallinto on tähän mennessä saanut kotiutettua eniten verotuloja - noin 
40 miljardin kruunun edestä - ja korostaa sopimusten ennaltaehkäisevää vaikutusta. Veropakolaisille ei ole enää tarjolla piilopaikkoja.

\subsection{Innovatiivinen Pohjola}

\subsubsection{Könbergin raportti - pohjoismaisen terveysyhteistyön selvitys}

Ruotsin entinen terveysministeri Bo Könberg sai kesällä 2013 tehtäväksi laatia ehdotuksen Pohjoismaiden terveysyhteistyön kohdentamisesta tulevina vuosina. Työn tavoitteena oli tuoda esiin terveydenhuoltoalan kysymyksiä, joita voidaan käsitellä paremmin pohjoismaisen yhteistyön avulla kuin kansallisesti.

Aloitteen terveysyhteistyön tarkemmasta analyysista esittivät alunperin Pohjoismaiden pääministerit vuonna 2012. Kimmoke tämän kaltaiseen kattavaan strategiseen selvitykseen saatiin niin kutsutusta Stoltenbergin raportista, jossa käsiteltiin Pohjoismaiden puolustus- ja turvallisuuspolitiikkaa.

Bo Könbergin laatima analyysi pohjautuu keskusteluihin Pohjoismaiden, Ahvenanmaan, Färsaarten ja Grönlannin keskeisten toimijoiden kanssa; keskusteluja käytiin terveysministerien, parlamentaarikoiden, etujärjestöjen, asiantuntijoiden ja laitosten kanssa.

Raportti luovutettiin kesäkuussa 2014 Islannin terveysministeri Kristján Pór Júlíussonille, joka otti sen vastaan Pohjoismaiden sosiaali- ja terveysministerien puheenjohtajana.

Raportti sisältää 14 konkreettista ehdotusta. Vuoden 2014 lopussa Pohjoismaiden sosiaali- ja terveysministerit päättivät priorisoida Könbergin ehdotuksista viittä osa-aluetta tulevien vuosien aikana:

- terveydenhuollon valmius

- erityistason sairaanhoito

- harvinaiset diagnoosit

- psykiatria

- virkamiesvaihto.

Lisäksi ministerit päättivät ottaa yhteyttä ulko- ja kehitysministereihin keskustellakseen työstä mikrobilääkeresistenssin torjumiseksi tehtävän ehdotuksen parissa. Asiasta keskustellaan Pohjoismaiden terveysministerien kokouksessa syyskuussa 2015. 
Pohjoismaiden ministerineuvoston vuoden 2015 toimintasuunnitelmaan sisältyy useita hankkeita, jotka ovat suoraan yhteydessä Könbergin raportin päätelmiin ja painopisteisiin.

\subsubsection{Nordic Built - ihmisen toivetalo}

Nordic Built -hankkeen käynnisti elinkeino-, energia- ja aluepolitiikan ministerineuvosto vuonna 2012. Hankkeen tavoitteena oli käynnistää ja tukea yhteispohjoismaisia rakennusalan energiatehokkuushankkeita, joilla on kansainvälistä vientipotentiaalia.

Ajatuksena oli hankkeen avulla edistää pohjoismaisen rakennussektorin kehittymistä johtavaksi toimijaksi Euroopassa ilmastomyönteisten ja innovatiivisten rakennusratkaisujen osalta.

Nordic Built -hankkeen tekee poikkeukselliseksi se, että ohjelma toi yhteen rakennusalan eri toimijoita tekemään yhteistyötä todellisen toivetalon luomiseksi; Nordic Built onnistui tuomaan yhteistyöhön muun muassa arkkitehtejä, asuinympäristöasiantuntijoita, sosiologeja ja tulevaisuudentutkijoita.

Nordic Built toteutettiin kolmen moduulin kautta: Nordic Built -peruskirja, Nordic Built Challenge -kilpailu sekä yhteispohjoismainen kehotus innovatiivisten ja ekologisesti kestävien korjausratkaisujen luomiseksi sekä businessmallien kehittämiseksi.

Nordic Built -peruskirjassa määriteltiin pohjoismaisen rakennusalan tavoitteet. Peruskirjan laadintaan osallistui 65 huippujohtajaa rakennusalalta. Peruskirja pohjautuu yhteispohjoismaisiin vahvuuksiin ja arvoihin ja siinä kuvataan periaatteita, joiden mukaan pyritään rakentamaan.

Nordic Built Challenge oli suunnittelukilpailu, jossa oli tavoitteena oli kokonaisvaltaisen ajattelun pohjalta remontoida viisi erilaista rakennusta eri puolilla Pohjolaa keskittyen erityisesti energiankäyttöön ja hiilidioksidipäästöihin - ja viihtyvyyden lisäämiseen.

Yli 130 pohjoismaista rakennusalan toimijaa on allekirjoittanut peruskirjan ja sitoutunut noudattamaan sen periaatteita.

Viiden eri rakennuksen omistajat ovat saaneet innovatiivisia ja kunnianhimoisia korjausehdotuksia keskittyen alan vahvuuksiin. Valittujen rakennusten joukossa on sekä asuintaloja että toimistorakennuksia. Tavoitteena on, että nämä viisi rakennusta toimisivat sekä lyhyellä että pitkällä aikavälillä inspiraationlähteinä ja esikuvina rakennusalalla sekä todisteena siitä, mitä alalla pystytään saavuttamaan, jos vain tahtoa löytyy.

Nordic Built päättyi vuoden 2014 aikana, mutta hankkeen konkreettiset hyödyt ulottuvat kauas tulevaisuuteen. 


\subsection{Näkyvä Pohjola}

\subsubsection{Pohjoismaiden kansainvälinen profilointi-ja asemointistrategia}

Pohjoismaiden yhteistyöministerit hyväksyivät Pohjoismaiden ensimmäisen kansainvälisen profilointi- ja asemointistrategian Pohjoismaiden neuvoston Tukholman-istunnon yhteydessä järjestetyssä kokouksessa.

Työ käynnistyi jo vuotta aiemmin. Tuolloin Pohjoismaiden ministerineuvosto panosti yhdessä Pohjoismaiden sekä Washingtonin Kennedy Center for Performing Arts -keskuksen kanssa suureen Nordic Cool 2013 -kulttuurifestivaaliin. Kulttuurifestivaalin yhteydessä haluttiin viestiä myös Pohjoismaiden arvoista. Järjestettiin seminaareja, joissa keskusteltiin tasa-arvosta, kestävyydestä ja avoimuudesta, ja pohjoismaisista arvoista viestittiin myös kampanjoissa ja medioissa. Tapahtumasta muodostui pohjoismaisen yhteistyön suurin mediamenestys. Varovaiset mittaukset osoittivat, että Yhdysvalloissa tavoitettiin 30 miljoonaa ihmistä ja kiinnostus oli lähes yhtä suurta myös Pohjoismaissa.

Nordic Coolin kokemuksia hyödynnettiin esitutkimuksessa, joka osoitti kaikilla yhteiskunnan aloilla olevan kiinnostusta Pohjoismaiden yhteisen profilointistrategian laatimiseen. Jokaisella Pohjoismaalla on oma strategiansa, mutta maissa ymmärretään, että Pohjoismaiden kaltaiset pienet maat voivat usein saavuttaa enemmän yhdistämällä voimansa. Monivuotisen ja aktiivisen pohjoismaisen yhteistyön ansiosta Pohjola voi tarjota yhteiset markkinat kaupankäynnille, työlle, tutkimukselle, koulutukselle, sekä avoimuuteen ja luottamukseen perustuvan yhteiskunnan ja lisäksi äärimmäisen kaunista luontoa. Voimme tarjota kokemuksia, jotka ovat luoneet pohjoismaisen hyvinvointimallin - eli pohjoismaista näkökulmaa.

Strategia pohjautuu pohjoismaisen mallin ydinarvoille, joita ovat:

- avoimuus ja usko kaikkien oikeuteen tuoda näkemyksensä ilmi

- ihmisten välinen luottamus ja vallan läheisyyden ansiosta luottamus myös yhteiskunnan johtoon

- lähimmäisen huomiointi, suvaitsevaisuus ja usko kaikkien ihmisten yhtäläiseen arvoon

- kestävä luonnon hallinnointi ja luonnonvarojen kehittäminen

- uudenlainen luovuuteen ja innovaatioihin panostava ajattelu. 
Pohjoismaiden ministerien toiveena on, että strategia toteutetaan yhteistoimin Pohjoismaiden kilpailukyvyn vahvistamiseksi ja kansainvälisen vaikutusvallan parantamiseksi.

\subsubsection{Tulevaisuuteen tähtäävää ilmastoviestintää}

Pohjoismaiden ministerineuvosto käynnisti jo vuonna 2013 erityisen ilmastoa koskevan viestintäpanoksen, joka suunnattiin nuorille aikuisille. Tämä kohderyhmä on vaikea saavuttaa ja se sivuutetaan usein ilmastoasioissa.

Panostus perustui vuosien mittaiseen toimivaan ilmastoyhteistyöhön Pohjoismaiden välillä ja sitä kutsuttiin ilmastokeskusteluksi. Pohjoismaiden ilmasto- ja ympäristöministerien lisäksi mukana oli tutkijoita, jotka osallistuvat kansainväliseen ilmastopaneeliin IPCC:hen.

Tavoitteena oli levittää IPCC-raportteihin koottua tietoa. Panostuksella oli monia tavoitteita: ensisijainen tavoite oli levittää tietoa ilmastotutkimuksen päätelmistä, mutta myös aiempaa selkeämmin tuoda näkyvyyttä ilmastonmuutoksen seurauksille. Lisäksi haluttiin nostaa esiin asioita, joita pitäisi ja joita voitaisiin tehdä ilmastonmuutoksen rajoittamiseksi, sekä toimien toteuttamisen tai toteuttamatta jättämisen seurauksia.

Koska kohderyhmänä oli nuoret aikuiset, Pohjoismaiden ministerineuvosto otti avuksi tunnettuja pohjoismaisia koomikkoja. Koomikot käsittelivät ilmastouhkia omalla tavallaan huumorin keinoin ilmastokampanjan puitteissa (http://www.norden.org/fi/pohjoismaiden-ministerineuvosto/ ministerineuvostot/ympaeristoeasiain-ministerineuvosto-mr-m/laitoksetyhteistyoeelimet-ja-tyoeryhmaet/tyoeryhmaet/ilmasto-ja-ilmaryhmaekol/videot-koomikot-puhuvat-ilmastonmuutoksesta).

Tältä huumoriin pohjautuvalta sivustolta on suora linkki sähköiseen työkaluun - joka myös on Pohjoismaiden ministerineuvoston rahoittama jossa voi interaktiivisesti valita erilaisia ilmastotoimia ja -panoksia ja nähdä ilmastolle eri valinnoista koituvat vaikutukset (globalweirding.is/here).

Tällä tavoin pohjoismainen yhteistyö viestitti vuonna 2014 painavaa tietopohjaista aineistoa vaikeasti saavutettavalle kohderyhmälle ymmärrettävässä ja pedagogisessa muodossa. 


\subsection{Ulospäin suuntautunut Pohjola}

\subsubsection{Ihmiskaupan vastainen työ}

Ihmiskauppa on vakava ihmisoikeusrikkomus. Pohjoismaiden ministerineuvoston ihmiskaupan vastainen työ pyrkii luomaan tuloksia kahdella tasolla. Toisaalta halutaan vahvistaa alalla tehtävää työtä mahdollistamalla tiedon- ja kokemustenvaihto sosiaaliviranomaisten, vapaaehtoisjärjestöjen, syyttäjien, poliisien ja muiden toimijoiden välillä Pohjoismaissa, Baltian maissa ja Luoteis-Venäjällä. Toisaalta ministerineuvosto haluaa tukea alueellista yhteistyötä kaikilla ihmiskauppaan liittyvillä aloilla ja alueilla yli maiden ja sektorien rajojen.

Pohjoismaiden ministerineuvosto on 2000-luvun alusta lähtien osallistunut aktiivisesti työhön, jonka tavoitteena on torjua ihmiskauppaa, asettaa ihmiskaupan toimijat oikeudellisesti vastuuseen teoistaan sekä suojella ja tukea ihmiskaupan uhreja.

Vuonna 2014 päättyi kolmivuotinen yhteistyöministerien käynnistämä ohjelma, johon osallistui useita alakohtaisia ministerineuvostoja. Pohjoismaiden ministerineuvoston toimistoilla Baltian maissa sekä Luoteis-Venäjällä oli aktiivinen rooli ohjelman täytäntöönpanossa yhteistyössä paikallisviranomaisten kanssa.

Ohjelma päättyi Pietarissa järjestettyyn Human Trafficking Today Our Joint Baltic Sea Challenge -konferenssiin. Konferenssissa keskityttiin Itämeren alueen ihmiskauppaan ja työhön, jota alueella on tehty muun muassa ministerineuvoston ja Itämeren valtioiden neuvoston puitteissa.

Ohjelman puitteissa sadat ihmiset ovat osallistuneet koulutuksiin sekä aiheeseen liittyviin konferensseihin, joita on järjestetty Pietarissa, Karjalan tasavallassa, Baltian maissa ja Helsingissä.

Vuonna 2014 ministerineuvosto käynnisti myös uuden kaksivuotisen aloitteen ihmiskaupan vastaisen työn jatkamiseksi. Tavoitteena on entisestään tehostaa yhteistyötä ja tiedonvaihtoa viranomaisten ja asiantuntijoiden muodostamassa verkostossa, joka tekee työtä näiden kysymysten parissa Pohjoismaissa, Baltian maissa ja Luoteis-Venäjällä.

\subsubsection{Yhteinen ääni tasa-arvoasioissa}

Pohjoismaiden tasa-arvopolitiikka on yksi pohjoismaisen demokratian kulmakivistä. Pohjoismaiden haasteet tasa-arvoalalla ovat samankaltaiset. Maat saavat paljon hyötyä toistensa kokemuksista ja hyödyntävät toistensa ratkaisumalleja edistääkseen sukupuolten välistä tasa-arvoa. 
Pohjoismaiden tasa-arvoalan yhteistyö on aktiivista ja näkyvää ja tasa-arvo on aivan selvästi yksi Pohjoismaita profiloivista arvoista myös kansainvälisesti.

Tasa-arvokysymyksissä Pohjoismaat puhuvat usein yhdellä äänellä ja sitoutuneesti. Kun esimerkiksi YK:n naisten asemaa käsittelevä toimikunta (CSW) piti vuotuisen kokouksensa vuonna 2014, Pohjoismaiden ministerit ilmaisivat yhteen ääneen tukensa koulutusalan aktiiviselle tasa-arvotyölle.

Toinen esimerkki oli Malmössä vuonna 2014 järjestetty pohjoismainen tasa-arvofoorumi, jonka pohjoismaiset naisasiajärjestöt järjestivät Pohjoismaiden ministerineuvoston huomattavalla tuella. Foorumissa keskusteltiin muun muassa oikeudesta samapalkkaisuuteen, yhtäläisistä koulutusmahdollisuuksista sekä nollatoleranssista sukupuoleen perustuvaa väkivaltaan kohtaan.

Kiinnostus Pohjoismaiden ministerineuvoston tasa-arvotyötä kohtaan oli suuri foorumin osallistujien keskuudessa.

YK:n naisten asemaa käsittelevän toimikunnan kautta Pohjoismaiden ministerineuvosto ja Pohjoismaat saavuttavat yhdessä parlamentaarikkoja, päätöksentekijöitä ja vapaaehtoisjärjestöjä, jotka osallistuvat toimikunnan kokouksiin. Niitä järjestetään joka vuosi, kun taas pohjoismainen foorumi on järjestetty vain kaksi kertaa aiemmin vuosina 1994 ja 1998. 


\section{Budjetti 2014 - Pohjoismaiden neuvoston kanssa käytyjen neuvottelujen seuranta}

Pohjoismaiden neuvoston ja Pohjoismaiden ministerineuvoston käymissä vuotuisissa budjettineuvotteluissa saavutettiin yksimielisyys ja alla olevat neuvoston suositukset huomioitiin vuoden 2014 budjetissa.

- Selvitetään, saataisiinko Pohjoismaisen kulttuurirahaston ja Pohjoismaisen kulttuuripisteen sijoittamisesta samaan paikkaan tehokkuuteen ja järkeistämiseen liittyviä etuja ja mitä vaikutuksia, etuja ja haittoja siitä olisi kulttuuripoliittiselle yhteistyölle.

Pohjoismaiden ministerineuvosto on käsitellyt suosituksen laatimalla selvityksen, jonka Pohjoismaiden neuvosto sai syyskuussa 2014. Kulttuuriministerineuvosto on käsitellyt selvitystä ja on sitä mieltä, että esitettyjen tietojen perusteella ei ole syytä jatkaa työtä Pohjoismaisen kulttuurirahaston ja Pohjoismaisen kulttuuripisteen yhdistämiseksi.

- Selvitetään, onko mahdollista saada tehokkuuteen ja järkeistämiseen liittyviä etuja yhdistämällä Oslossa pohjoismaisessa keskuksessa toimivan kolmen erillisen organisaation hallinnolliset toiminnot. Laitosten ohjausta selvitetään osana pääsihteerille annettua uudistustehtävää.

NordForsk, Pohjoismainen energiantutkimus ja Nordic Innovation ovat saaneet tehtäväksi toteuttaa taloudellisesti ja hallinnollisesti kestävän yhteisen hallintomallin. Malli on ensin luotava, ja tavoitteena on ottaa se käyttöön vuosina 2015-2016. 
- Pohjoismaiselle lehtimieskeskukselle myönnetään 1000000 Tanskan kruunua tavoitteena edistää toimittajatyötä, jolla on selkeät pohjoismaiset tavoitteet. Työ rahoitetaan erästä 1-2208-1 Strategiset panostukset.

Pohjoismaiden ministerineuvosto on huomioinut Pohjoismaiden neuvoston kanssa tehdyn budjettikompromissin myöntämällä Pohjoismaiselle lehtimieskeskukselle 1000000 Tanskan kruunua. Toiminnan painopiste on Pohjoismaille tärkeissä kysymyksissä keskittyen toimittajien ja journalistien uusiin työtapoihin ja rooleihin, jotka avaavat uusia mahdollisuuksia eri tiedotuskanaville Pohjoismaissa.

- Puheenjohtajamaan erän käyttämättömistä varoista kohdennetaan yhteensä 300000 Tanskan kruunua Pohjoismaiden itsehallintoja koskevan esityksen 41/2012 toteuttamiseen vuonna 2014.

Ministerineuvosto osallistui esityksen toteuttamiseen myöntämällä määrärahaa Pohjoismaiden itsehallintomalleja koskevan julkaisun laatimiseen ja siihen liittyvän konferenssin järjestämiseen. Yhteistyöministerit hyväksyivät budjettineuvottelujen yhteydessä 400000 Tanskan kruunun myöntämisen tähän tarkoitukseen. Pohjoismaiden neuvosto hallinnoi työtä julkaisun ja konferenssin parissa ja teki sopimuksen Ahvenanmaan rauhaninstituutin kanssa toteutuksesta.

- On tarvetta edistää kansainvälistä yhteistyötä, jonka avulla kehitetään toimenpiteitä kasvavan mikrobilääkeresistenssin torjuntaan (One Health). Sen vuoksi ehdotetaan, että alueen yhteispohjoismainen panostus nostetaan etusijalle suunniteltaessa kansanterveystieteen tulevaa pohjoismaista yhteistyötä ja tehtäessä siitä päätös vuoden 2014 alussa Pohjoismaisen kansanterveystieteen korkeakoulun (NHV) lakkauttamisen seurauksena.

Tämä on yksi Pohjoismaiden ministerineuvoston painopistealueista. Yhteistyöministerit ovat käsitelleet Könbergin raportin kokonaisuudessaan sekä siihen kuuluvan ehdotuksen mikrobilääkeresistenssistä. Islannin terveysministeri ja Islannin ulkoministeri (joka on myös kehitysministeri) ovat keskustelleet asian käsittelemisestä myös muiden Pohjoismaiden ulko- ja kehitysministerien kanssa. Kysymystä on käsitelty myös maa- ja metsätalous-, kalastus-, vesiviljely- ja elintarvikeasiain ministerineuvoston kokouksissa vuosina 2012-2014. Lisäksi Pohjoismaiden ministerineuvoston sihteeristö on useaan otteeseen 
neuvotellut Maailman terveysjärjestö WHO:n kanssa

mikrobilääkeresistenssistä. Pääsihteeri on muun muassa tavannut WHO:n aluejohtaja Zsuzsanna Jakabin. Yhteistyöministerit tekevät edelleen määrätietoisesti työtä kysymyksen parissa.

- Kestävän kuluttajapolitiikan näkemyksiä tuodaan selkeämmin esiin ympäristöalan kestävää kulutusta ja tuotantoa käsittelevän työryhmän uudessa työsuunnitelmassa.

Työryhmä on vuoden 2015 työohjelmassaan nostanut esiin ainoastaan kestävän kulutuspolitiikan kysymyksiä ja tekee yleisesti laajalti aihepiiriin liittyvää työtä.

- Nordjobbin budjetista kohdennetaan varoja Jobbresan-hankkeen markkinoimiseksi Pohjoismaiden kunnille.

Nordjobb on toiminnastaan kertovissa kokouksissa Pohjoismaiden kuntien ja työnantajien kanssa esitellyt myös Jobbresan-hankketta mallina auttaa työmarkkinoiden ulkopuolelle joutuneita nuoria (NEET, Not in Education, Employment or Training) löytämään työtä. Nordjobb tekee aktiivisesti työtä työllisyysasteen parantamiseksi niiden nuorten keskuudessa, joka ovat yliedustettuina työttömyystilastoissa (NEET-nuoret ja lukion jälkeisistä oppilaitoksista vastavalmistuneet).

- Pohjoismainen kesäyliopisto (NSU) siirretään Nordforskin alaisuuteen sillä edellytyksellä, että NSU:n toimintataso pysyy samana. NordForsk saa tehtäväksi rahoittaa NSU:n toimintaa vuonna 2014 vuotta 2013 vastaavalla tasolla.

Pohjoismaiden ministerineuvosto on käsitellyt tämän Pohjoismaiden neuvoston suosituksen NordForskin vuoden 2014 ohjauskirjeessä, jossa laitokselle annetaan tehtäväksi rahoittaa Pohjoismaista kesäyliopistoa vuonna 2014 vuotta 2013 vastaavalla tavalla. Pohjoismainen kesäyliopisto ja NordForsk ovat allekirjoittaneet sopimuksen rahoituksesta vuodelle 2014.

- Varataan 0,5 miljoonaa Tanskan kruunua esitutkimukseen tavoitteena dokumentoida tarkemmin verkossa julkaistavan yhtenäisen pohjoismaisen tiedon tarvetta pienille ja keskisuurille yrityksille, jotka aikovat palkata henkilöstöä tai toimia rajojen yli Pohjolassa tai aloittaa toimintaa toisessa Pohjoismaassa. Esitutkimus tehdään yhteistyössä yritysyhdistysten kanssa. Juutinrauman alueella on jo tällainen alueellinen verkkoportaali, mutta palvelua voitaisiin tarjota 
pienille ja keskisuurille yrityksille kaikissa Pohjoismaissa. Esitutkimus rahoitetaan budjettierästä Raja-alueyhteistyö 5-2055-1.

Rambøll laati vuonna 2014 tarveanalyysin pohjoismaisesta tiedotusportaalista pienille ja keskisuurille yrityksille. Raportin päätelmänä oli, että eri Pohjoismaissa on paljon tietoa ja että tämä tieto tulisi saattaa laajasti yritysten saataville, jotta ne saisivat yhdestä paikasta kattavan yleiskatsauksen. Raportissa ehdotetaan useita tapoja suunnitelman toteuttamiseksi.

Sihteeristö on vuonna 2014 pyrkinyt selvittämään, mitä tahoja voitaisiin ajatella toimeksiannon toteuttajiksi. On myös selvitetty, mitä vaihtoehtoisia tapoja portaalin rahoittamiseksi voisi olla. Näin ollen on olemassa selkeä pohja päätöksenteolle koskien ratkaisun kehittämistä, kunhan portaalin ylläpitoon ja rahoittamiseen liittyvät kysymykset saadaan ratkaistua.

- Budjettierään 7-8113-2 (Vihreät tekniset normit ja standardit Pohjoismaat suunnannäyttäjinä) sisällytetään myös arviointi Pohjoismaiden rakennusalan yhtenäistämisestä.

"Pohjoismaat suunnannäyttäjinä" on vuodesta 2012 lähtien ollut osa pääministerien vihreän kasvun aloitetta. Ohjelma kattaa rakennusalan kolmen yhteisen standardisointitoimen kehittämisen. Ohjelman tavoitteena on tehdä yhteispohjoismaisista standardeista eurooppalaisia. Rakennusalan olemassa olevien standardien yhtenäistäminen on jatkuvasti ollut asialistalla Pohjoismaiden standardisointijärjestöjen ja pohjoismaisten laitosten välisissä keskusteluissa. Käsitys on se, että on viisasta resurssienkäyttöä varmistaa EU- ja Eta-sääntöjen yhteinen yhtenäistäminen ja täytäntöönpano ja siten ehkäistä uusien rajaesteiden syntymistä.

- Liikenne sisällytetään uuteen energiapoliittisen yhteistyön toimintaohjelmaan (2014-2017). Liikennealan tutkimusta ja innovointia tulee myös arvioida Pohjoismaisen energiantutkimuksen uuden energiantutkimusohjelman (2015-2018) laatimisen yhteydessä.

Energiaan liittyvät liikennekysymykset kuuluvat horisontaalisena aihealueena Pohjoismaiden energiapoliittisen yhteistyön toimintaohjelmaan 2014-2017. Erityisesti priorisoidaan sähköautoja ja liikennesektorin uusiutuvaa energiaa. Alan konkreettisena hankkeena energiapolitiikan virkamieskomitea (ÄK-E) on päättänyt tukea biopolttoaineen kehittämistä lentokoneille. Lisäksi myös liikenne sisältyy Pohjoismaisen energiantutkimuksen strategiaan. 
- Budjettierästä Työryhmät - ympäristö (3-3311-2) kohdennetaan varoja Helsingin komission Helcomin Itämeren suojelun toimintaohjelman (BSAP) täytäntöönpanoon.

Ympäristösektorin meriympäristön työryhmä (HAV) on vuonna 2015 korvamerkinnyt noin 400000 Tanskan kruunua Helcomin hankkeisiin. Lisäksi suuri osa työryhmän työstä liittyy Helcomiin.

- Tarvitaan pohjoismainen selvitys potilaiden vapaasta liikkuvuudesta Pohjoismaissa uuden EU-direktiivin (direktiivi potilaiden oikeuksien soveltamisesta rajatylittävässä terveydenhuollossa) kansallisen täytäntöönpanon ja ensimmäisten kokemusten saamisen jälkeen. Asia sisältyy Pohjoismaiden ministerineuvoston suureen Kestävä pohjoismainen hyvinvointi -ohjelmaan 2013-2015, jonka osana sitä arvioidaan parhaillaan käynnissä olevan terveydenhuoltoalan yhteistyön tarkastelun yhteydessä.

Tätä kohtaa käsitellään Könbergin raportin ehdotuksessa 7, joka koskee potilaiden vapaata liikkuvuutta ja joka korostaa, että Pohjoismaiden tulee arvioida potilaiden vapaata liikkuvuutta koskevan EU-direktiivin täytäntöönpanon vaikutuksia. Vielä on kuitenkin aikaista arvioida direktiivin vaikutuksia. Yhteistyöministerit tekevät sen vuoksi edelleen työtä potilaiden vapaan liikkuvuuden parissa, ja direktiivin kansallista täytäntöönpanoa käsitellään yhteistyöministerien tulevassa kokouksessa. 
Pohjoismaiden ministerineuvosto

Ved Stranden 18

DK-1061 København K

www.norden.org 